\title{
The Economy, the War in Iraq and the 2004 Presidential Election
}

\author{
CEFOS Working Paper 6 \\ 2006
}

Douglas A. Hibbs, Jr.*

CEFOS

*douglas@douglas-hibbs.com

douglas.hibbs@cefos.gu.se

\section{CEFOS}

Centrum för forskning om offentlig sektor - Center for Public Sector Research www.cefos.gu.se 
CEFOS Working Paper 6

The Economy, the War in Iraq and the 2004 Presidential Election

(C) Douglas A. Hibbs, Jr., 2006

ISSN: 1653-3895

\begin{tabular}{|c|c|}
\hline \multirow{2}{*}{\multicolumn{2}{|c|}{ CEFOS }} \\
\hline & \\
\hline Centrum for forsknıng om offentlıg sektor & Center ror Pubilc sector \\
\hline $\begin{array}{r}\text { Gôteborgs universitet } \\
\text { Box } 720\end{array}$ & $\begin{array}{l}\text { Gotedorg University } \\
\text { P.O. Box } 720\end{array}$ \\
\hline 40530 Göteborg & SE-405 30 Göteborg, Sweden \\
\hline office@cefos.gu.se & office@cefos.gu.se \\
\hline Tel. 031-773 414 & Tel. +46 317734142 \\
\hline www.cefos.gu.se & www.cefos.gu.se \\
\hline
\end{tabular}




\title{
The Economy, the War in Iraq and the 2004 Presidential Election
}

\author{
Douglas A. Hibbs, Jr. \\ CEFOS, Göteborg University \\ douglas@douglas-hibbs.com
}

\begin{abstract}
In this paper I apply the Bread and Peace model of voting in US presidential elections to analyze the sources of George W. Bush's narrow re-election victory in 2004. The aggregate election outcome is readily explained by the model's objectively measured political-economic fundamentals - no appeal need be made to arbitrarily coded count, trend or dummy variables. The results imply that the 2004 election turned mainly on weightedaverage growth over the term of per capita real disposable personal income. The war in Iraq, which has escalated dramatically in political relevance since the 2004 contest, had a relatively small impact on the election result, probably depressing Bush's two-party vote share by less than a half percentage point.
\end{abstract}

George W. Bush achieved a relatively narrow re-election victory in the 2004 presidential election. Yet unlike his victory as the Republican challenger in the 2000 election when he won the Electoral College vote but received fewer popular votes than the Democrat's candidate $\mathrm{Al}$ Gore, in 2004 Bush attracted a $51.24 \%$ majority of the total Bush/Cheney v. Kerry/Edwards popular vote. ${ }^{1}$

My analysis of how development of the economy and the war in Iraq affected the 2004 election outcome is based on the "Bread and Peace" model introduced in Hibbs (2000) which analyzed the period 1952-1996. The model assumes that postwar American presidential elections for the most part should be interpreted as a sequence of referendums on the White House party's economic record. My research showed that politically relevant economic performance is best measured by a weighted-average of quarterly growth rates of per capita real disposable personal income, computed from the election quarter back to the first full quarter of each presidential term. ${ }^{2}$ Growth of per capita real disposable personal income is probably the broadest single aggregate measure of changes in voters' economic well-being in as much as it includes income from all market sources, is adjusted for inflation, taxes,

\footnotetext{
${ }^{1}$ I compute the two-party share from the official tally of the Federal Election Commission at http://www.fec.gov/pubrec/fe2004/federalelections2004.shtml.

${ }^{2}$ I first proposed the weighted-average real income growth setup in Hibbs (1982).
} 
government transfer payments and population growth, and tends to move with changes in unemployment. ${ }^{3}$

The only additional factors I found that significantly affected votes for President in the postwar era were the discretionary US military interventions in the Korean and Vietnamese civil wars. My research indicated that the electoral penalties exacted by Korea and Vietnam fell almost wholly on the party of the President initiating the commitment of US forces (the "war party," in both those cases the Democrats), and were proportionate to the cumulative numbers of American military fatalities at the relevant election dates. Regression experiments determined that the "grace period" for new presidents inheriting US interventions in Korea and Vietnam ran a full term. The implication was that the 1956 vote for Dwight Eisenhower (who inherited American involvement in the Korean civil war from Harry Truman) was unaffected by US military fatalities in Korea after Eisenhower assumed office in 1953, and that the 1972 vote for Richard Nixon (who inherited US engagement in the Vietnamese civil war from Lyndon Johnson) was unaffected by US fatalities in Vietnam after Nixon assumed office in 1969. Hence up until the 2004 contest, the electoral effects of US military interventions were felt mainly in 1952 and $1968 .^{4}$

It should be emphasized that the Bread and Peace model is designed to explain voting outcomes in terms of political-economic fundamentals rather than optimally to predict elections using pre- election poll data on voter sentiments, preferences and the like. Such attitudinal variables are themselves generally affected by objective fundamentals and for that reason supply no insight into the ultimate causes of voting behavior. Applying the model to the 2004 election, I place the American invasion of Iraq (but not Afghanistan) on the same footing as US involvement in Korea and Vietnam, to wit: An unprovoked hostile deployment of American armed forces in a foreign conflict never sanctioned by a formal Congressional declaration of war.

\footnotetext{
${ }^{3}$ However, disposable personal income of course does not register benefits voters perceive from government supplied goods and services.

${ }^{4}$ Cumulative over-the-term US military fatalities at the 1952 and 1968 election dates were 29,260 and 28,896, respectively, as compared to just 414 over the term preceding the 1976 election, at which point the incumbent (Nixon-) Ford administration had exhausted the estimated one-term "grace period."
} 


\section{THE BREAD AND PEACE MODEL}

The Bread and Peace equation has a simple nonlinear functional form:

$$
\text { Vote }_{t}=\alpha+\beta_{1}\left(\sum_{j=0}^{14} \lambda^{j} \Delta R_{t-j}\left(1 / \sum_{j=0}^{14} \lambda^{j}\right)\right)+\beta_{2} K I A_{t}
$$

where

- Vote is the percentage share of the two-party presidential vote going to the candidate of the incumbent party

- $\quad R$ is per capita disposable personal income deflated by the Consumer Price Index; $\Delta R_{t}$ is the annualized quarter-on-quarter rate of growth, $\log \left(R_{t} / R_{t-1}\right) \cdot 400$. At the election quarter $(j=0)$ the weighting parameter $\lambda^{j=0}=1$ is scaled down to $1 / 3$ because of the within-quarter date of presidential elections (the first Tuesday following the first Monday of November)

- KIA is the cumulative number of American military fatalities (in 1000s) over the presidential terms preceding the 1952 (Korea), 1968 (Vietnam), 1976 (Vietnam) and 2004 (Iraq) elections.

\section{Estimates, Fits and Predictions}

Table 1 reports nonlinear-least-squares estimates of the Bread and Peace equation for the $\mathrm{N}=14$ presidential elections spanning 1952-2004. ${ }^{5}$ The model was fit using data available as of July 2006 on disposable personal incomes from the Bureau of Economic Analysis, data on the consumer price index (all urban workers) from the Department of Labor, and data on US military fatalities in Korea, Vietnam and Iraq from the US Department of Defense. According to the coefficient estimates in Table 1, each percentage point of growth in per capita real disposable personal income sustained over the presidential term boosts the in-party candidate's vote share by around 3.6 percentage points above a benchmark constant of approximately 46 percent. In addition, the incumbent's vote share is depressed by about 0.3

\footnotetext{
${ }^{5}$ The Stata program and data file used to generate all results in this paper are available at http://www.douglashibbs.com/Election2004/election2004_update.htm.
} 
percentage points per 1000 American military fatalities owing to hostile, discretionary deployments of US armed forces in unprovoked wars.

Table 1. Bread and Peace Equation Estimates

\begin{tabular}{lccc}
\hline Incumbent Vote Share & $\begin{array}{l}1952-2004 \\
\text { Adj } \mathrm{R}^{2}=.826\end{array}$ & $\begin{array}{c}\mathrm{N}=14 \text { elections } \\
\text { Root MSE }=2.42\end{array}$ & \\
& $\frac{\text { Coef. Estimate }}{\text { Std. Error }}$ & $\underline{\text { t-ratio }}$ \\
Constant $(\alpha)$ & 46.2 & 1.24 & 37.3 \\
Real Income Growth $\left(\beta_{1}\right)$ & 3.61 & 0.615 & 5.87 \\
Weighting parameter $(\lambda)$ & 0.914 & 0.058 & 15.9 \\
Cumulative KIA $\left(\beta_{2}\right)$ & -0.307 & 0.078 & -3.95 \\
\end{tabular}

Expressed on an annual basis, the weighted-average per capita real income growth rate during Bush's first term was $1.72 \%$. US military fatalities in Iraq stood at 1.13 thousand at the end of October 2004. The within-sample prediction (regression fit) of Bush's two-party vote share from the Bread and Peace model is therefore $52.08 \%$, implying a prediction error of $-0.84 \%: 46.2+3.61 \cdot 1.72-0.307 \cdot 1.13 \simeq 52.08 ; 51.24-52.08=-0.84$. These model estimates indicate that the Iraq war made only a small dent in the vote for Bush - depressing his two-party share by approximately $1 / 3$ of a percentage point. However, if casualties continue to mount all the way up to the next election, Iraq could have decisive effect in 2008, particularly if on economic grounds alone the election would likely be close. But in 2004 the fundamental source of Bush's re-election was real income growth over the term.

The out-of-sample prediction of the 2004 election result is almost as good as the withinsample prediction-fit. Estimation of the model over the sample range 1952-2000 yields coefficients nearly identical to the full sample estimates ( $\left.\hat{\alpha}=46.3, \hat{\beta}_{1}=3.59, \hat{\lambda}=0.91, \hat{\beta}_{2}=-0.309\right)$. The one-election-ahead, out-of-sample prediction of Bush's two-party vote share is $52.16 \%$, which gives a prediction error of $-0.92 \%$. George Bush's narrow 2004 victory is then very well accounted for by the political-economic 
fundamentals in the Bread and Peace model. Table 2 shows actual and in-sample predicted vote shares for all elections in the postwar sample generated by the estimates in Table 1, along with the election period values of the weighted-average real income growth and cumulative KIA independent variables. 
Table 2. Candidates, Votes, Predictions and Performance

\begin{tabular}{|c|c|c|c|c|c|c|}
\hline $\begin{array}{l}\text { In-Party v. } \\
\text { Out-Party } \\
\text { Candidates }\end{array}$ & $\begin{array}{l}\text { Election } \\
\text { Year }\end{array}$ & $\begin{array}{c}\text { Incumbent } \\
\text { Party \% } \\
\text { Vote Share }\end{array}$ & $\begin{array}{c}\text { Predicted } \\
\% \text { Vote } \\
\text { Share }\end{array}$ & $\begin{array}{c}\text { Regression } \\
\text { Prediction } \\
\text { Error }\end{array}$ & $\begin{array}{l}\text { Weighted- } \\
\text { avg. Real } \\
\text { Income } \\
\text { Growth }\end{array}$ & $\begin{array}{l}\text { Cumulative } \\
\text { KIA (1000s) }\end{array}$ \\
\hline $\begin{array}{l}\text { Stevenson v. } \\
\text { Eisenhower }\end{array}$ & 1952 & 44.60 & 45.90 & -1.30 & 2.40 & 29.260 \\
\hline $\begin{array}{l}\text { Eisenhower v. } \\
\text { Stevenson }\end{array}$ & 1956 & 57.76 & 56.65 & 1.11 & 2.89 & 0.00 \\
\hline $\begin{array}{l}\text { Nixon v. } \\
\text { Kennedy }\end{array}$ & 1960 & 49.91 & 49.28 & 0.63 & 0.85 & 0.00 \\
\hline $\begin{array}{l}\text { Johnson v. } \\
\text { Goldwater }\end{array}$ & 1964 & 61.34 & 61.43 & -0.09 & 4.21 & 0.00 \\
\hline $\begin{array}{l}\text { Humphrey v. } \\
\text { Nixon }\end{array}$ & 1968 & 49.60 & 48.23 & 1.37 & 3.02 & 28.896 \\
\hline $\begin{array}{l}\text { Nixon v. } \\
\text { McGovern }\end{array}$ & 1972 & 61.79 & 59.27 & 2.52 & 3.62 & 0.00 \\
\hline Ford v. Carter & 1976 & 48.95 & 50.00 & -1.05 & 1.08 & 0.414 \\
\hline $\begin{array}{c}\text { Carter v. } \\
\text { Reagan }\end{array}$ & 1980 & 44.70 & 44.82 & -0.12 & -0.39 & 0.00 \\
\hline $\begin{array}{l}\text { Regan v. } \\
\text { Mondale }\end{array}$ & 1984 & 59.17 & 60.16 & -0.99 & 3.86 & 0.00 \\
\hline $\begin{array}{l}\text { GHW Bush v. } \\
\text { Dukakis }\end{array}$ & 1988 & 53.94 & 54.41 & -0.47 & 2.27 & 0.00 \\
\hline $\begin{array}{l}\text { GHW Bush v. } \\
\text { Clinton }\end{array}$ & 1992 & 46.55 & 47.58 & -1.03 & 0.38 & 0.00 \\
\hline $\begin{array}{l}\text { Clinton v. } \\
\text { Dole }\end{array}$ & 1996 & 54.74 & 49.98 & 4.76 & 1.04 & 0.00 \\
\hline $\begin{array}{l}\text { Gore v. GW } \\
\text { Bush }\end{array}$ & 2000 & 50.27 & 54.75 & -4.49 & 2.36 & 0.00 \\
\hline $\begin{array}{c}\text { GW Bush v. } \\
\text { Kerry }\end{array}$ & 2004 & 51.24 & 52.08 & -0.84 & 1.72 & 1.130 \\
\hline
\end{tabular}




\section{Scaling US Military Fatalities to Population}

The US population grew from 158 million at time of the 1952 election to 295 million at the time of the 2004 election. A sensible refinement of the original Bread and Peace model would be to scale the KIA variable by population size. ${ }^{6}$ Expressed per million US population, cumulative fatality rates among US armed forces at the 1952, 1968, 1976 and 2004 election dates were 196.8, 152.4, 2.08 and 3.86, respectively. As shown by Table 3, re-estimating the Bread and Peace equation with KIA scaled to population yields a small improvement to the model's fit. Aside from the parameter of the re-scaled KIA variable, however, the coefficient estimates are nearly identical to those of Bread and Peace model with cumulative military fatalities not scaled to population size. The within-sample prediction of Bush's 2004 twoparty vote share is $52.23 \%$ and so the prediction error about $-1 \%$ : $46.3+3.55 \cdot 1.73-0.05 \cdot 3.86 \simeq 52.23 ; 51.24-52.23=-0.99$. As before the estimates imply that the Iraq war had only minor impact on the 2004 vote, decreasing Bush's vote share by perhaps little as $1 / 5$ of a percentage point.

Table 3. Bread and Peace Equation Estimates with KIA scaled to population

\begin{tabular}{lccc}
\hline Incumbent Vote Share & $\begin{array}{c}1952-2004 \\
\operatorname{Adj~R}^{2}=.836\end{array}$ & $\begin{array}{c}\mathrm{N}=14 \text { elections } \\
\text { Root MSE }=2.35\end{array}$ & \\
& $\underline{\text { Coef. Estimate }}$ & $\underline{\text { Std. Error }}$ & $\underline{\underline{\text { t-ratio }}}$ \\
Constant $(\alpha)$ & 46.3 & 1.20 & 38.5 \\
Real Income Growth $\left(\beta_{1}\right)$ & 3.55 & 0.595 & 6.03 \\
$\begin{array}{l}\text { Weighting parameter }(\lambda) \\
\begin{array}{l}\text { Cumulative KIA } \\
\text { per million population }\left(\beta_{2}\right)\end{array}\end{array}$ & 0.908 & 0.057 & 16.0 \\
& -0.050 & 0.012 & -4.15 \\
\hline
\end{tabular}

\footnotetext{
${ }^{6}$ Nordhaus (2006:317) mentions that scaling to population would be more appropriate and I agree.
} 
Figure 1 graphs the strong connection of votes for President to real income growth over the term. (The regression line in blue is based on Table 3 estimates; Table 1 estimates would have shown a nearly identical relation.) Cumulative US military fatalities at the times of the 1976 and 2004 elections were too small to exert much influence. The big KIA effects were in 1952 (Korea) and 1968 (Vietnam). In both cases the high fatality levels (29,260 or 196.8 per million population in Korea and 28,896 or 152.4 per million in Vietnam) most likely deprived the in-party Democrat candidates of victory. However, as I mentioned earlier, things may be different in 2008. By the end of October 2006 American military fatalities in Iraq had reached 2816, a US exit strategy had not yet materialized, and the accumulation of American bodybags was showing no sign of slowing down.

Figure 1. Bread and Peace Voting in US Presidential Elections

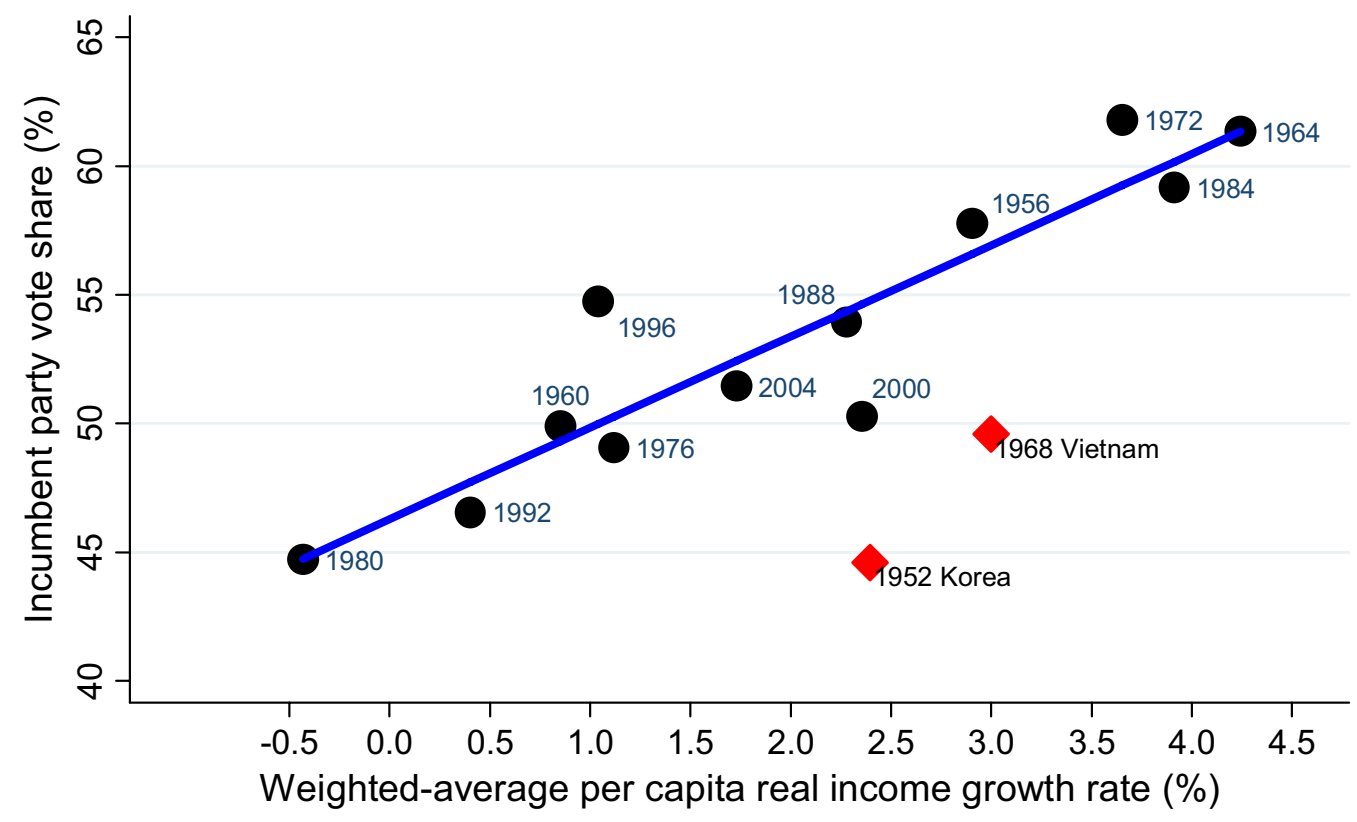

The only postwar presidential election results not well accounted for by the Bread and Peace model are 1996 and 2000. The vertical deviations of the 1996 and 2000 outcomes from the regression line are noticeably larger in those non-war years than in all the others. (See also the regression errors in Table 2.) A partisan of the Bread and Peace like myself model might be tempted to conjecture that idiosyncratic influence of candidate personalities took 
especially strong form in 1996 and 2000 - with the ever charming Bill Clinton looking especially attractive when pitted against the darkly foreboding Bob Dole in 1996, and the unfailingly wooden Al Gore paling by comparison to the affable George Bush in 2000. This line of reasoning is of course entirely ad-hoc and without scientific standing.

\section{NORDHAUS ON HIBBS VIS-A-VIS FAIR}

In a recent article in the Quarterly Journal of Political Science William Nordhaus argues that the 2004 election outcome represents a "statistical defeat" for voting models that are based on fundamentals - a conclusion founded mostly on results Nordhaus obtained from analysis of various equations developed by his Yale economics colleague Ray Fair (Nordhaus 2006). However Nordhaus also makes claims about the adequacy of the Bread and Peace model and its prediction of the 2004 election result, although discussion of that model appears to be something of an afterthought to his main focus on Fair's equations. ${ }^{7}$ The following assertions made by Nordhaus are incorrect:

- Nordhaus claims that "the forecast error [of the Bread and Peace model] for the incumbent vote margin in 2004 was ... 4 percentage points" (Nordhaus 2006:317, $318)$.

It is unclear to me exactly how Nordhaus computed a 4 percentage point prediction error for Bush's margin using the Bread and Peace model. Nordhaus's paper will give many readers the impression that he subjected my equation to the same analysis procedures he applied to Fair's equations - estimation of rolling regressions using the most recently available economic data to compute in-sample predictions (i.e. conventional regression fits) and out-of-sample (one-election-ahead) predictions of the incumbent two-party vote share. But no information pertaining to my model appears among the "full documentation with data, statistical programs, and regression files $\ldots$ available at http://www.econ.yale.edu/ nordhaus/homepage/elec/qjps.htm" (Nordhaus 2006:314). Nor was I successful in obtaining specific information from Nordhaus about his investigation of my model by direct request (twice).

\footnotetext{
${ }^{7}$ Nordhaus discusses results from five different sets of regression and forecasting experiments undertaken with a subset of Fair's many specifications.
} 
As far as I can tell Nordhaus just consulted a table of election forecasts I posted at my web site in July 2004 about the implications of the Bread and Peace model for Bush's likely vote share under different assumptions about real income growth rates and the numbers of Americans killed in Iraq during the run-up to the November election date. ${ }^{8}$ However this may be, when placed on the same footing as Nordhaus's analysis of Fair's various equations, the Bread and Peace model delivers in-sample and out-of-sample prediction errors for Bush's 2004 vote margin that are less than 2 percentage points The margin variable used by Nordhaus is just twice the conventional regression residual (or prediction) error. For example, the Bread and Peace model's in-sample and out-of-sample errors of $-0.84 \%$ and $-0.92 \%$ discussed at Table 1 therefore translate to vote margin errors of $-1.68 \%$ and $-1.84 \%$, respectively. Further, my point estimates of the effect of Iraq on Bush's vote share - in the range $-1 / 5$ to $-1 / 3$ of a percentage point - imply an impact on Bush's margin of approximately -0.4 to -0.67 percentage points, as opposed to "an estimate of around [minus] 1.3 percentage points using Hibbs's equation" reported by Nordhaus (Nordhaus 2006:317). ${ }^{9}$

- Nordhaus also claims to have made "an attempt to extend the Hibbs equation back to 1916" and "found that the "peace" variable became insignificant" (Nordhaus 2006:317, n.9).

A far as I know, and as far as the Bureau of Economic Analysis at the Department of Commerce (which maintains the US National Income and Product Accounts) knows, quarterly data series on disposable personal income begin in 1947. Hence I do not see how it would have been possible for Nordhaus to estimate the Bread and Peace model back to 1916 using the proper income variable. In any case, the hostile deployments of American forces in Korea, Vietnam and Iraq have nothing in common politically with American involvement in the World Wars. Fair evidently sees things the same way. In a piece posted at his web site after the 2004 election he wrote that his dummy variable WAR, which as noted ahead Fair added to his initial model later in order to pick up fillips to incumbent vote shares at elections

\footnotetext{
${ }^{8}$ See Nordhaus 2006:317, n.8.

${ }^{9}$ A problem with all of Nordhaus's computations is that he puts Bush's two-party vote share at $51.6 \%$ (which evidently was obtained from preliminary data available at some point at Fair's web site) as opposed to the official tally of $51.24 \%$. A small "error in dependent variable" therefore contaminates Nordhaus's various 2004 regression-prediction experiments.
} 
during the World War I and II periods, "has nothing to do with wars like Korea, Vietnam and Iraq.” (Fair 2004:3-4)

- Although Nordhaus acknowledges that the 2004 "forecast error" of the Bread and Peace model was "much smaller than Fair's equation" (errors from various Fair equations ran from -8.1 to -15.4 percentage points in 2004), he asserts that the Bread and Peace model "has larger errors than the Fair approach for most election years back to 1952." (Nordhaus 2006:317)

Here again Nordhaus's claim is incorrect. The average absolute value of regression residual errors for the fourteen presidential elections spanning 1952-2004 generated by the Bread and Peace model and shown in Table 1 is 1.49 percentage points. The data reported in Nordhaus's background documentation web page yield corresponding average absolute value residual errors of $1.97 \%$ for what Nordhaus calls the "new Fair" equation, and $2.9 \%$ for what he (mistakenly) calls the "original Fair" equation, over the same fourteen elections. Contrasting the Bread and Peace results to Nordhaus's data for the "new" and "original" Fair equations also shows that the absolute values of regression residual errors for both of those Fair specifications is greater than the corresponding errors for the Bread and Peace model for 9 out of the 14 presidential elections.

The standard errors of the regression (root mean square errors) reported in Nordhaus's background documentation for various Fair equations that Nordhaus re-estimated over 19162004 run from 2.37 to 4.07, as compared to 2.42 in Table 1 (and 2.35 in Table 3) for the Bread and Peace model. In a popular discussion of his research posted after the 2004 election, Fair (2004) reported a standard error 2.37 for his current equation. What should one make of regression standard errors and other fit statistics turned in by Fair's equations?

The list of linear regressors in the model favored by Fair initially (the actual "original" equation settled upon in Fair 1978), expressed in terms of the two-party vote share going to the incumbent party, ${ }^{10}$ were: (1) a Party "switching" term equal to +1 when the Democrats held the White House and -1 when the Republicans did, (2) a time trend $t$ taking positive trend values during Democrat incumbencies and negative values during Republican ones, (3)

\footnotetext{
${ }^{10}$ Until the 2004 election Fair used the two-party vote share of the Democrat's presidential candidate as the dependent variable rather than the incumbent party vote share, and this required multiplying through his regressors (except the trend) by a Party "switching" term equal to +1 when the Democrats were incumbent and -1 when the Republicans were.
} 
a binary variable $D P E R$ coded +1 when a sitting President was a candidate and 0 otherwise, (4) the election year growth rate of per capita real output $G$, and (5) the absolute value of the average growth rate of GNP deflator over the two years (eight quarters) up to the election, $P_{8}$. This original model was revised repeatedly in the years to follow. ${ }^{11}$

In a 1984 update Fair replaced $G$ with the per capita output growth rate in the $2^{\text {nd }}$ and $3^{\text {rd }}$ election year quarters only, $G_{2}$, and he redefined Ford's 1976 candidacy as non-incumbent so that the DPER coding changed from +1 to 0 in that election. The computation of $P_{8}$ was also lagged one quarter back from the election quarter.

In a 1988 update the initial trend term, $t$, was replaced by a new trend, $t^{*}$, that stopped increasing in 1976.

In a 1992 update $G_{2}$ was replaced by the per capita real output growth rate in the first three quarters of the election year, $G_{3}$, a new "good news" variable $N-G O O D_{2.9}$ was added that was equal to the number of quarters over the term in which the annualized per capita growth rate exceed 2.9 percent, $P_{8}$.was replaced by the inflation rate over 15 pre-election quarters, $P_{15}$, the (revised) trend term $t^{*}$ was dropped, and a new trend variable $D U R_{3+}$ was added that was coded 0 if the incumbent party had been in office for one or two consecutive terms, +1 if in office for three consecutive terms, 1.25 if in office for four consecutive terms and so forth by increments of 0.25 . Finally, a third new variable WAR was added that took values of +1 at the 1920, 1944 and 1948 elections, and 0 otherwise. At those same three elections the empirical values of $P_{15}$ and $N-G O O D_{2.9}$ (but not $G_{3}$ ) were set to zero.

In a 1996 update the growth rate threshold for "good news" was raised from 2.9 to 3.2 percent $-N-G O O D_{3.2}$. And the $D U R_{3+}$ variable was redefined so as to kick in with a value of +1 at the second rather than the third consecutive term, before increasing by increments of 0.25 for each additional consecutive term following the second $-D U R_{2+}$.

We have quite a remarkable stream of re-specifications which - to his credit - Fair faithfully cataloged, made publicly available, and freely admitted were wholly motivated by attempts to fit better aggregate voting outcomes as one election followed the other. As Fair

\footnotetext{
${ }^{11}$ The sequence of Fair's re-specifications summarized below are discussed in greater detail in a series of update documents posted at http://fairmodel.econ.yale.edu//vote2008/index2.htm. The equation that Nordhaus calls the "original Fair specification" is really Fair's initial 1978 equation after elimination of the secular trend term - an important modification that Fair did not make himself until 1992, fourteen years after his original equation appeared in print.
} 
recently conceded "Much searching over many years has been done in arriving at the final [2004] version." (Fair 2004:5) A clear implication is that Nordhaus's appeal to the favorable magnitudes of standard errors and fits prior to the collapse of the most recent vintage of Fair's model in 2004 has no foundation in standard statistical inference - a point first driven home to economists by Ed Leamer in his famous 1978 book Specification Searches: Ad Hoc Inference with Nonexperimental Data.

Nor is Fair's model composed predominantly of "fundamentals," if one takes the common sense view (as I do) that fundamentals logically consist of objectively measured policies and performance affecting voters. Indeed four of the seven regressors in Fair's current equation are various trend, dummy and switching terms whose coding has nothing to do with objective policies and performance and everything to do with tracking fillips to the time path of voting outcomes that his equations otherwise are unable to accommodate. ${ }^{12}$

\section{CONCLUSIONS}

George W. Bush won a relatively narrow victory in the 2004 election that is very well accounted for by objective measurement of economic performance in the Bread and Peace model - in particular the weighted-average growth rate of per capita real disposable personal income over the term. One need not resort to coded trend, dummy or switching variables to understand the voting outcome.

The count of American military fatalities in Iraq, which in principle might have had great electoral consequences, stood at 1,130 at the end of October 2004. That number was insufficient to exert big effect on the 2004 election. Between November 2004 and November 2006, however, American military fatalities increased 2.5 fold. If flow of American military personnel killed continues at anything like this pace, Iraq may well prove decisive in the 2008 election. But in 2004 the election turned mainly on a real income growth record just favorable enough to keep the Republicans in the White House.

\footnotetext{
${ }^{12}$ Bartels (1997) provides a biting critique targeted on Fair's relentless efforts to pick up jots and wiggles of the data with the comings and goings of various coded variables.
} 


\section{References}

Bartels, Larry. 1997. "Correspondence: econometrics and elections." Journal of Economic Perspectives 11: 195-97.

Fair, Ray. 1978. "The Effect of Economic Events on Votes for President." Review of Economics and Statistics 60:159-172.

Fair, Ray. 2004. "A Vote Equation and the 2004 Election." at http://fairmodel.econ.yale.edu/vote2004/vot1104a.pdf.

Hibbs, Douglas. 1982. "President Reagan's Mandate from the 1980 Elections: A Shift to the Right?” American Politics Quarterly 10:387-420.

Hibbs, Douglas. 2000. "Bread and Peace Voting in U.S. Presidential Elections." Public Choice 104:149-180.

Leamer, Edward. 1978. Specification Searches: Ad Hoc Inference with Nonexperimental Data.

Nordhaus, William. 2006. "Electoral Victory and Statistical Defeat? Economics, Politics and the 2004 Presidential Election." Quarterly Journal of Political Science 1:313-322. 